821.163.41.09:398

811.163.41'374

https://doi.org/10.18485/mks_srpska_slavistika.2018.2.ch34

\author{
Миодраг С. МАТИЦКИ* \\ Иниститут за књижевност и уметност у Београду \\ Вукова задужбина
}

\title{
ВУКОВЕ ПРИЧЕ О РЕЧИМА
}

\begin{abstract}
У Српском рјечнику из 1818. године налазимо обиље наративних записа који показују да се, тада, Вук увелико учио како да усмено казивање преточи у писани запис, кратак и ефектан у мери да буде прихваћен од стране слушалаца. Велики мајстори српске поезије и прозе наслутили су колики се мајдан митских слојева, претакања легенди у мит, поетског сензибилитета, наративне фикције и сновиђења крије у народним приповеткама, посебно оним кратким, пре свега у Вуковим причама о речима у Српском рјечнику.

Кључне речи: Вукове приче о речима, Српски рјечник, народне приповетке, мит.
\end{abstract}

Након књиге Српске народне приповијетке (2017) - у којој су, поред Вукове истоимене збирке објављене у Бечу 1853 , сабране и остале Вукове приповетке из посебних издања: прештампана руковет из додатка Новина сербских (1821), приповетке из рукописа које је објавила 1870. Вукова удовица Ана, а припремила његова кћер Мина, као и оне приповетке за које Вук вели да су народне у његовом бечком забавнику Данищи - приредио сам и другу књигу Вукових приповедака под насловом Приче о речима. У ову књигу уврстио сам кратке приповедне форме којима је Вук Караџић тумачио речи у Српском рјечнику $(1818 ; 1852)$ и Народним српским пословицама и другим различним као оним у обичај узетим ријечима (1836). Књига Приче о речима покушај је реконструкције сложеног пута стасавања Вука Караџића као приповедача и сакупљача српских народних приповедака. Осим тога, желео сам да ова књига буде од велике помоћи проучаваоцима српске уметничке прозе, посебно оне настале после појаве Српског рјечника.

У Српском рјечнику из 1818. године налазимо обиље наративних записа који показују да се, тада, Вук увелико учио како да усмено казивање преточи у писани запис, кратак и ефектан у мери да буде прихваћен од стране слушалаца. Тако се калио вештини мајстора редиговања српске усмене прозе, развијао урођени таленат

*maticki.miodrag@gmail.com 
да дотерује усмени запис, некада тек синопсис народне приче коју је чуо и није могао да директно бележи како је то чинио са песмама, стих по стих. Научио је да своју усмену прозу дотерује у складу са усменим приповедањем које је подразумевало директно обраћање и перформансу, са свим покретима и речитим паузама којима се одржава пажња слушалаца.

У српској књижевној периодици 18. и 19. века су и иначе деценијама предност имале кратке приче са поентом, којима се ,држала” пажња читалаца, чије се упориште налазило у анегдоти вешто истргнутој из хроничарског приповедања, а све то се садржавало у основи усменог казивања. Скраћивања су претежно остваривана уз помоћ уметања пословица и ,у обичај узетих речи”, фразама које су биле опште препознатљиве. То је срж изванредне Вукове народне приче и једна од основа „новог правца у српској књижевности" за који дугујемо Вуку не само због реформе језика и писма већ и због, ако не радикалног заокрета у српској прози 19. века, а оно свакако због преусмерења уметничке приповетке.

Овакав приступ потврђује српска књижевна периодика Вуковог доба, пре свега она коју уређују вуковци првога реда, мада не треба занемарити да су и Вукове приповетке обилно прештампаване у листовима, алманасима и календарима, и то, као што је био случај са народним песмама, не све и одреда, тако да се може начинити типологија прештампавања српске усмене прозе у периодици која је замењивала недостатну аутентичну српску прозну продукцију. Тако се стварала јединствена, општа српска усмена баштина, издвајало оно највредније у локалној традицији.

Народна приповетка почела је да преко књижевне периодике знатније утиче на прозне писце уношењем кратких прозних усмених облика, позајмљивањем ликова, ситуација, досетки усменог постања. Читаве руковети Вукових народних прича заискриће у српској прози, па и комедији. Само на основу мотива надлагивања (,Лаж за опкладу”, „Лажа и паралажа”), надмудривања са свецима и ђаволом, написане су многе успеле шаљиве приче и комедије.

Аутори српске поезије и прозе наслутили су колики се мајдан митских слојева, претакања легенди у мит, поетског сензибилитета, наративне фикције и сновиђења, ослобађања хумора владањем њиме као средством ослобађања личности од свакодневља и невоља, крије у народним приповеткама, посебно оним кратким, пре свега у причама о речима. Вуковим приповеткама нису се без разлога окретали српски писци друге половине 20. века, чак и припадници најмодернијих праваца у српској књижевности. Незаобилазни су прилози Иве Андрића о Вуку (девет студија, есеја, пригодних осврта и чланака), антологије усменог/народног стваралаштва Васка Попе (Од злата јабука, 1958; Урнебесник, 1960; Поноћно сунце, 1962), великог романсијера Бошка Петровића, аутора романа о Тешану Подруговићу - Певач, који је, са Стојаном Трећаковим, изабрао и приредио у издању Матице српске малу антологију Вукових „прича о речима” (Мале приче, 1987; друго, допуњено издање - 2000). Када је реч о пословицама и изрекама као својеврсним причама о речима посебно је значајна књига Радомира Константиновића, који је у издању Просвете 1964. године, о стогодишњици Вукове смрти, објавио књигу Расковник. Проза из Рјечника, пропраћајући свој избор веома значајном студијом. У дослуху са Васком Попом, Миодраг Поповић је 1983. године објавио књигу о Српском рјечнику Вука Стеф. Караџића - Памтивек, јединствени портрет ове Вукове књиге која је коперникански 
преокренула токове српске књижевности и српског књижевног језика. Већим делом он се дотиче кратких прозних форми којима је Вук тумачио у обичај узете речи, биле оне згуснуте у пословице, изреке, веровања у оно „што не може бити”, или усменог памћења о митским и историјским личностима које су обележиле историју српског народа. Миро Вуксановић, уредник едиције Матице српске „Десет векова српске књижевности", као прозни писац који је најлепше странице своје прозе посветио речима, приредио је 2012. године за ову едицију Вуков Српски рјечник. У уводној студији открио нам је постмодернистичке Вукове предлошке који се тичу жанра речника-романа какав је у 20. веку у свет изнео Милорад Павић са својим Хазарским речником (1984) а, да додамо, наслутио га још Ђорђе Марковић Кодер у својим причама о роморењу као прапочетку језика.

Голуб Добрашиновић је сабрао Андрићеве текстове о Вуку Караџићу, почев од његове приступне беседе у САНУ изговорене 24. 1. 1946, у књигу Иво Андрић о Вуку (1977) на основу које је Бошко Сувајџић показао да је Андрић „вуковску традицију недвосмислено изабрао и декларативно обзнанио као своју” (Сувајџић 2017: 112-113), окрећући се Вуку као писцу особитог духа и технике књижевног израза (Исто: 117), као приповедачу кога из прошлости занима пре свега „жива старина” (Исто: 118), те да је преважно што је Скерлић Вуков „тобожњи романтизам” одредио и ограничио Вуковим ,„рационалистичким духом”. Сувајџић закључује свој прилог закључком да се ,открива несумњива духовна присност између Андрића и Вука, исказана у Андрићевим есејима, али и имплицитно, у њиховом стилу и језику”, посебно када је реч о оној линији Андрићевог приповедања која води „до Вука и његове народне приповетке, до матрице народне књижевности и поетике усменог обликовања" (Исто: 123).

О овим везама Андрића са Вуком говоре најсликовитије историјска проза, Андрићева ослањања на Вукове кратке историјске приче о речима које се тичу живог традицијског памћења историје српског народа. Тако у Андрићевим романима и приповеткама са историјском основом, подвизи јунака, често наопаки, могу да оживе само у приповедању окренутом огледалу колектива. Кратке и упечатљиве историјске слике које се нуде као „приче о речима”, и код Андрића „оверава” паремијска свест колектива. Оне су живе и упечатљиве на вуковски начин само зато што Андрић црпи наративно искуство из Вукових кратких прича о речима у којима и ликови, и веровања, и мотолошка предања, и оно што чини усменом вековима памћену историју народа, што опстојава и доживљава се као писана метаморфоза усменог. Тек тако преточени, писмом фиксирани, сведени на кратку причу о речима, историјски ликови и историјске сцене оживљавају у свести читалаца за сва времена, захваљујући снази високодометног историзирања романа и романсирања историје. Свега тога чаробног не би било у Андрићевој историјској прози да нема тог колективног огледала у који читалац урања, призван волшебном Вуковом фразом која упозорава на вазда живу усменост, на снагу усменог казивања и обраћања слушаоцима као једином живом репрезенту колектива. Та фраза се у Српском рјечнику понавља стотинама пута као шлагворт и она гласи: „људи приповиједају”. 
На тој линији српске прозе заживео је снажан ток историјског приповедања који можемо да пратимо, захваљујући Доситеју, чак од 18. века, а свакако да га препознамо утврђеног у Мемоарима Проте Матеје Ненадовића, у варошким причама Љубе Ненадовића, преко Петра Кочића, све до Иве Андрића и Бранка Ћопића, при чему посебно треба издвојити прозу Растка Петровића у којој се на веома суптилан начин бележи оно што ,људи говоре”.

Највећи значај за заокрет српске књижевности ка откривању живе књижевне традиције има песник Васко Попа. Он је шездесетих година 20. века подстакао и подржао професора Ђорђа Трифуновића да начини Србљак. Службе, канони, акатисти I - III (1970; рукопис је био спреман за штампу још 1967), да готово на длану писцима примакне богату средњовековну књижевну баштину. И данас, захваљујући томе, протрајава гласна и откривалачка линија духовне лирике у српској поезији. А такве песме певали су српски песници у 18. и почетком 19. века, називајући их nсалми. То су били и наслови рубрика интимне духовне лирике у првим српским периодицима, да би у Новинама сербским 1820. године Лукијан Мушицки превод псалме први означио новим термином: „ода духовнија”, и нешто потом, за књиге црквеног садржаја, извео назин ,духовна сочињенија”. Убрзо за рубрику такве лирике уредници књижевних периодика стављају ознаку: „Духовна поезија”.

Својим антологијама које је објавио готово у серији (Од злата јабука, 1958; Урнебесник, 1960; Поноћно сунце, 1962) Попа је понудио посве ново читање баштине српског народа, упоредо доказујући у својим песмама колико и у модерној поезији могу бити продуктивни и подстицајни усмени и средњовековном књижевношћу подстакнути жанровски облици. У првој антологији у низу, Попа креће са кључним порукама, најдубљим разлозима свог окретања народној књижевности. Мото његова уводника чине два цитата из бајки (реч је о прози у којој се описује нешто што је измаштано, нешто што није реално, како Вук вели „,то не може бити”). Први је цитат из бајке Златна јабука и девет пауница о рађању јабуке златним плодовима, а други из приповетке Немушти језик, у којем се истиче оно што је за језик најбитније, да се уз волшебне стваралачке потицаје може развити његова расковничарска природа и помоћи човеку да може да проникне у све тајне битија и збитија: „Чобан пође кроз шуму, и идући чујаше и разумеваше све што говоре тице и траве и све што је на свету". У потоњој Руковети народних умотворина Попа даје повеће одломке из ових и других бајки. Реч је, како потом вели у уводу, „о плодовима златне јабуке на гранатој воћки човекове маште”, о надограђивању и обогаћивању овога света речима песме, о доприносу усменог певача, народа, - „нашег првог песника” (Попа 1979а: 7-8). Овакав Попин приступ део је новог програма који он тих година наслућује, па чак у светској књижевности и чује како се остварује. Тај се нови препород, у нас, по њему, ,овога пута, заснива на поново откривеним темељима и стубовима народне уметности” тако ,да можемо само да се поносимо поетским благом свога народа, јер не морамо лутати по свету”. Истовремено прориче: „Загонетним, никад до краја одгонетнутим трагом те родне понорнице једино се може допрети до срца света и учинити да се чује један бар откуцај његов и гласом наше земље и наших људи” (Исто: 9).

У руковетима народних умотворина Попа бира оне записе у којима до изражаја долази чаробност нашег језика, изоставља епске песме због дужине (и не само због 
тога), а у прегрштима, вешто их компонујући, читаоцима пружа чаробну антологију: кратких прича о речима и одломака дужих бајки (Цариград, Тамни вилајет, Златна јабука и девет пауница, Немушти језик), пословица, загонетки о крунским појмовима (сунце, месец, звезде, земља, ветар, муња, дуга, очи, глава, језик, говор, срце), брзалица, бројаница, басми, клетви, заклетви.

Можда се у издвојеној загонетки Мртвац и носиоци му крије поетска Попина загонетка о упрегнутом коњу који има осам ногу: „Пет тијела, четири душе, сто ноката”, или је у оној о каишу који се састаје на ,пупчи-пољу” и загонетки о барки „Мртви живога носи преко непочин-поља”, Попа нашао заметак свог симбила који носи једну збирку његових песама - Непочин-поље. Попа, можда, баш у бајаличкој бројаници од урока у којој се користи као лековито понављање речи чудо (чудан човек, чудна њива, чудно рало, чудна бразда), да би се поентирало синтагмом „чудна змија” („Не чудим се чудној змији, но се чудим Милановом уроку”, открио њему омиљену поетску слику: „чудно чудо” (Исто: 48), или је у басми од црвеног ветра открио „зев над зевовима": земља зину (Исто: 158).

Другом антологијом, Урнебесник, Попа је у свом препородном програму отишао корак напред. То је, у ствари, читанка хумора у српској књижевности у којој усменом стваралаштву, посебно краћим прозним формама, припада значајно место. Он је то усмено благо имао на уму док је слагао хронолошким низом остварења песника новије српске књижевности „у којима ликује прави хумор”, оно што је „за собом оставило дубљи песнички траг” и што садржи „поносна и пркосна знамења хумора" (Попа 1979б: 7-11). Пре избора Попа пружа избор одломака из есеја о хумору под насловом Мали речник хумора, у којем окупља савременике који су се, на неки начин, већ укључили у нови препород српске књижевности који је подразумевао откривалачки начин окретања усменом стваралаштву и традицији. Попа издваја прилоге Исидоре Секулић, Марка Ристића, Сретена Марића, Павла Стефановића, Коче Поповића, Ели Финција, Зорана Мишића, Зорана Глушчевића и Боре Ћосића. То су, махом, припадници крука око „Нове литературе”, око НОЛИТА. Свакако да би посебно била занимљива антологија усменог/народног хумора коју је Попа помињао као вредан подухват који неко треба да оствари, да би на том плану до пуног изражаја дошла кратка Вукова народна приповетка, пре свега анегдота која је продужила живот басана у 19. веку.

Али Васко Попа је успео да начини волшебну антологију Поноћно сунце (1962), у којој нам је открио „Кључеве сновиђења”. Под тим насловом, он на почетку зборника доноси одломке из текстова Лазе Костића, Марка Ристића, Сретена Марића, Зорана Мишића и Зорана Глушчевића. Опет је реч о кругу припадника новог препородног покрета око НОЛИТА, у који је као родоначелник укључен велики песник Лаза Костић. Васко Попа истиче у предговору да су књигу, која носи симболично значење Поноћно сунце, принели читаоцима песници, да су „поноћно сунце исковали, чини нам се, од самих загонетака без одгонетке [...] изнели су га из својих виђења с ове или оне стране земље и неба". Износећи примере сновиђења насталих на „сновном тлу”, сазданих ,,језиком свемогућих преображавања”, Попа успева да нам открије ,како се укида смртоносна несразмера између нас и свеколиког свемира, очухински равнодушног према нама”, како можемо да се „изједначујемо са самим непрекидним свемирским стварањем”, да „владамо том звезданом чаролијом 
и у исти мах јој служимо”. И, на крају, пита се: „Није ли сваки од ових светова који овде, пред нашим очима настају у ствари салик или нелик или пралик овог нашег света јаве?" (Попа 1979в: 7-9).

У овој књизи усмено стваралаштво добија своје право место. Попа се опредељује за тумачења снова (Народни сановник), питалище, изреке, предања. Он чак доноси 22 предања о настанку појединих космонима, топонима, животиња: „Предања о постанку света”, „Звезде, земља, човек”, „Гром”, „Вода”, „Вјетар”, „Камење”, „Вук”, „Корњача”, „Пчела” [...] Реч је, у ствари, о кратким причама о речима. Тако нас је Васко Попа навео на прави пут откривања велике теме о кратким причама о речима у Вуковим књигама Српски рјечник и Народне српске пословице и друге различне као оне у обичај узете ријечи, помогао нам да уочимо колико су усмени жанрови умрежени и повезани када је реч о примању и разумевању појединих појмова који чине координате српске духовности. У тим причама о речима некада се, готово притајено, наслућује загонетка, чује питалица, оно што ,људи приповиједају”, поука анегдоте, маштарија из бајке, казивање „о ономе што не може бити”, да би се, често, све зачинило пословицом која само релативно важи за сва времена, јер је зависна и од ваката и од људи. Све у овим причама остаје заталасано, могуће, отвотрено да се доприча и надогради. У томе је срж усмености, усменог преношења с колена на колено, а не у петрифицирању и заувек датим порукама. Управо на том плану започета су опозициона конфронтирања у просуђивању Вуковог дела која ће понајбоље одредити наслов књиге Меше Селимовића: За и против Вука (1967).

Свега две године после појаве Попиног трећег зборника Поноћно сунце, о обележавању стогодишњице Вукове смрти, Радомир Константиновић креће са унапред одређеном, и већ петрифицираном тезом о пословицама као делу епског вуковског канона који је деценијама ретроградно деловао када је реч о иновацијама и продору модерних струјања у српској књижевности, управо тежњом да се све утврди и зацементира десетерцем, пословицом и изреком, у обичај узетим речима, да се „памтивек” усмено чуваног свакодневног искуства и мудровања, историјског искуства и промишљања добрих и злих сила, учини затвореним, за свагда датим, простором усмености. У том кључу пословице проглашава круном свођења мудрости и искуства. У сржи његовог предговора избору кратких Вукових прича (Константиновић 1964) крије се клица опозиционих надгорњавања на плану утврђеном синтагмом Меше Селимовића „За и против Вука!” По њему пословице, као утврђене фразе, наводе на помишљај да су оне круна за свагда утврђене усмено памћене историје српског народа, „памтивека” мудрости и искуства које је српски народ стекао кроз туробне векове искушења, ропства и буна, да су оне сам врх погубног леденог брега епског канона који као фатум притиска српски народ кроз векове. Истовремено, оне су потврда да Вуков епски канон доприноси затварању свести народа за свака модернија искушавања певања и мишљења, за сваки модернији наговештај светске литературе. Исти је случај, вели он, и са загонеткама, за које постоји само један „одгонетљај”.

Прилика је да подсетимо да је забележено више десетина опречних пословица и загонетки о Богу, на пример, о човеку, срећи, да су се оне међусобно поништавале, и у разговарању веома често потирале, као и да загонетања не би било да није постојала могућност два, па и више „одгонетљаја” како су то говорили почетком 
19. века. Константиновић је превидео живи принцип усмености на делу, разговор на граници надгорњавања и окушавања речима што чини суштину усмене прозе типа „људи говоре”, која се, како Вук вели, тешко може и бележити док се не стекне ситуација у којој настаје, која је повод да се нека од тих краћих усмених прозних форми уопште и употребе. Свакако је то проза која отвара и упућује вазда на приповедне странпутице, на зачињања хумором, на увођење у причу живих, присутних слушалаца, на призивање сведочанства како би се приповедано потврдило макар и „фиктивном збиљом” (о виђењу вила и вештица). Подуга епска песма о женидби Душановој сведена је у завршним стиховима на пословицу исковану у десетерцима: „Тешко свуда своме без својега!” А, истовремено, у колективној свести лелујају и варијанте пословица о брату који када ископа брату око, гледа да то учини дубоко. Или, прича о кумству као светињи и ујму своди се у шаљивој Вуковој причи о речима (ујам у Српском рјечнику из 1818) на пословицу, боље рећи на у обичај узете речи које се понављају као подука са паремијском основом. Кад се издалека угледају кумови, сељак што доноси жито куму да му самеље вели у себи: „Благо мени! Ево мога кума, самлеће ми без ујма”! А кум млинар истовремено помишља: „Благо мени! Ево мога кума, даће ми два ујма”! Управо усменост, краткоћа прича о речима, причама претходницама пословица о понашањима људи у одрећеним ситуацијама, при чему се користе и драмски елементи, отворили су писцима у Вуковом Српском рјечнику мајдан наративних модела и омогућили да до данас захватају са тог извора усмености крепка наративна искуства која помажу српским прозаистима да узлете, да се укључе у модерне струје приповедања, да српску прозу учине самосвојнијом и препознатљивом у шару мозаика светске литературе. Треба напоменути да, на пример, под речи юемушти језик Вук у другом издању Српског рјечника (1852) упућује на подужу народну приповетку, наглашавајући да се само ту налази њено тумачење и њена употреба. Значи, Вуков Српски рјечник је за апстрактне, митолошком маглом потиснуте речи, дозвољавао и могућност коришћења и подуже приче о речима као најпоузданије илустрације значења.

Конфронтирање Радомира Константиновића ставовима Васка Попе у великој мери осветљава природу Вукових прича о речима и оних из којих су проистекле пословице. У предговору Расковника Константиновић креће од истих Попиних кључних упоришта којима дочарава моћ усменог приповедања када је реч о сновиђењима, од тамног вилајета и истоимене Вукове бајке:

„Тамни вилајет, царство без могуће одлуке и решења, јер без својих правила, без унутрашњег свог реда и поретка у које би дух могао да проникне и, тако, да изиђе на видело овога света, био је исконска опасност за епског човека, велика негативна инспирација за највише тренутке нашег епског стварања и, можда, чак и нека таква инспирација и за самога Вука, који је ваљда управо у коби тамно-вилајетске безизлазности нашао подстицај за свој граматичарски занос, за своју потајну али моћну веру у интегралну граматичност света, у моћни ред и поредак који владају њиме и који омогућавају разрешење свега загонетног, крајње простим одговорима, тријумфалним као што су сви „одгонетљаји” на загонетке [,Загонетка је увек порицање загонетног”, вели на једном месту Константиновић - М. М.]. Није ли чак и сам Вуков фонетски правописни принцип израз ове тежње, овога типично епског нашег веровања у савршену једноставност света, израз прадревног напора да се порекне све недокучиво и тамно, да се управо предухитри и оспори противуречје које, за епски дух, шта би могло друго да буде него пустиња тамног вилајета?” (Константиновић 1964: 8-9) 
Константиновић потпуно другачије тумачи појам расковника, траве која помаже да се све ствари на свету учине јасним. По њему, када је у питању свест, маштање и дозвољавање права да се ствари могу сагледати на више начина, расковник је погубан и пре има значење заковника, само такав подобан је епском вуковском канону:

„Епски дух упућен је методи; он је принуђен да верује у њу. Осуђен је на оптимизам несамерљив, на овај расковничарски, оптимистички рационализам: или тамни вилајет, беспуће у колебању свуда, у свему, или свеопшти склад, механички једноставан, који расковник омогућава и дозива! Читаво стварање епског човека зато је тражење методе, што боље и што савршеније, сан о универзалној методи, тражење расковника".

Константиновић се у свом есеју обара на отпор епског канона случајностима и непредвидивом, на епског човека расковничара који је у суштини „граничар”, који се највише страши безграничног. Он се чак индиректно упушта у полемику са Васком Попом. По њему:

,техника савремене поезије која покушава да се надахне Вуком и његовим Рјечником није ништа друго него техника заборављања ових одгонетки, тог јемства границе и ограничавања, кућевног, као кућа затвореног. Ми, ипак, хоћемо кућу да заборавимо а епски човек, епски расковничарски дух у Вуку хоће кућу, ту што редовнију редовност живота, ону баш коју ликујући слави пословица" (Исто: 14).

Пословица је, вели Константиновић, у славу куће створена, пре свега је пословица-кућаница, пословица-правило и део закона редовног ,под који епски дух хоће све да подведе, сваки покрет и сваки случај” (највише је реч о животним ситуацијама које и чине суштину приповедања, свакако басана и кратких прича са клицом подуке - прим. М. М.). По Константиновићу и смех који налазимо у причама које претходе пословицама ,увек је у име правила и закона а на рачун отпадника и, уопште, отпадништва од правилности” (Исто); захваљујући пословицама ,закон тријумфује а не прича" (Исто: 16). Константиновић у овом контексту наслућује и нешто битно што се тиче наративности кратких прича о речима, посебно оним које претходе пословицама:

„Можда зато овај говор не познаје раскошност. У његовој простоти, у некаквом сталном унутрашњем сужавању система све ужих концентричних кругова [овим Константиновић отвара питање холограмске структуре кратких прича о речима - прим. М. М.], у напору ка апсолутној концентрацији, ка есенцијелности лексиконске фразе којом Вук пише увек и не само у 'Рјечнику', као да се слути иста воља за правилом а не за причањем, воља која води у сиромаштво, али не принудно сиромаштво које нас, данас, често угрожава, не, дакле, по невољи духа који свуда види, и кад неће, закон, правило једног поништавајућег уопштавања, већ сиромаштво вољно, сиромаштво које подразумева ова верност правилу закона. То сиромаштво је у тражењу границе и ограничења (генезом из одгонетке на загонетке, из обичаја и веровања), јер у тражењу свемоћне технике, у обећању оног универзалног метода-расковника као јемству максималне сигурности” (Исто).

Свој предговор Константиновић завршава поређењем стила Вукове наративности у кратким причама о речима са Доситејевом фразом. У Вуковој фрази он види ,епско тражење сигурности”, недостатак неочекиваног, непознатог, чак и присенка будућности, коначност и неизменљивост избора речи и њиховог значења, не налази никакве игре маште. Вукове реченице су кратке, у њој глагол има брзо и моћно дејство. Ништа се не препушта ћудима реченице и вољи језика. Насупрот 
томе, Доситеј је умео да проговори о „бездну”, о „оцеану” у који одлазе све људске речи, сва људска говорења. Константиновић се пита: „Где је тај бездан у Вуковој прози? Кад се он Вуку отворио?” (Исто: 19)

Бошко Петровић, у сарадњи са Стојаном Трећаковим, објавио је у издању Матице српске избор прича о речима из Вукова оба издања Српског рјечника (1818; 1852), под насловом Мале приче (1987; 2000 - допуњено издање), као и из народних пословица. Сматрао је да су те приче пошто служе као објашњења речи и изрека „остале углавном незапажене”: „Читалац лако прелази преко њих и исто их тако заборавља". У овој књизи приче о речима су тек делом представљене; избор је сведен на „мале приче, у ствари анегдоте, превасходно хумористичке; изузевши три-четири унеколико другачије, којима, по начину како су сачињене и причане, место у овој књизи неће бити спорно”. У књигу су унесени и неколики записи из Рјечника: „Они нису приче, него као неки одмори између њих, али нити ће се косити с њима, нити ће бити наодмет читаоцу” - следи закључак кратке „Белешке уз књигу” приређивача (Петровић, Трећаков 2000: 150).

У оквиру едиције Матице српске „Десет векова српске књижевности”, као десету књигу по реду, Снежана Самарџија је приредила избор усмене Вукове прозе под насловом Народне приповетке и предаға (2017) и пропратила га својим уводним прилогом о одликама усмене прозе под насловом „Причам ти причу” и одломцима најрелевантнијих научних прилога о овој тематици. Од онога што је Вук написао, издвојила је као преважно становиште да „у писању приповијетки већ треба мислити и ријечи намјештати (али опет не по своме вкусу, него по својству српскога језика), да не би ни с једне стране било прећерано, него да би могао и учен читати, и прости слушати" (Исто: 247). Такође, С. Самарџија у напомени скреће пажњу да „термином мале приповетке Вук обухвата све прозне варијанте које штампа као секундарну грађу, када тумачи речи и пословице. Објединио их је по форми, тј. сведеној композицији, док су облици различити (басне, шаљиве приче, анегдоте, фрагменти бајке и новеле, предања, веровања, приче из живота, етнографски описи и цртице)". С. Самарџија битним сматра да су за Вука народне приповетке биле посебно важне због језика: „Као што су пјесме углед језика наше народне поезије, тако ће ове приповијетке бити углед народног језика у прози", при чему је истицао једнако важним записе из Бачке и Срема, као и оне из Херцеговине и Боке Которске (Исто: 248). Одломак преузет од Вука С. Самарџија с разлогом закључује Вуковом напоменом да се и народне приповетке, као и песме, могу поделити на мушке и женске: „Женске су приповијетке оне у којима се приповиједају којекаква чудеса што не може бити (и по свој прилици само ће за њих бити ријеч гатка, њемачки Marchen); а мушке су оне у којима нема чудеса, него оно што се приповиједа рекао би човјек да је заиста могло бити. Многе су мушке приповијетке смијешне и шаљиве”. У студији Наде Милошевић Ђорђевић „Преглед прозних облика наше усмене књижевности" С. Самарџија издваја запажање да Вук у предговору неколиким приповеткама одјављеним у Давидовићевим Новинама сербским и издатим као посебно издање 1821. године, „први систематично указује на њене врсте, да би у својој збирци из 1853. пружио и пуни преглед богатства наративних облика" (Исто: 249). Што се тиче предања која ће Вук унети као етнолошку грађу у своју књигу Живот и обичаји народа српског (1867), која се, такође, находи и у оба издања Српског 
рјечника, Нада Милошевић Ђорђевић сматра да се треба држати поделе која је назначена у поглављима Вукове књиге Живот и обичаји народа српског: 1. етиолошка и есхатолошка предања; 2. историјска и културноисторијска; 3 . демонолошка и митолошка; 4. легенде, као међународна група са којом се „не подудара ни једна категорија Вукове етнографске грађе у овој књизи" (Исто: 250). Пошавши од постулата да је Вук стилизовао, прекрајао и враћао у „природно” стање записе народних приповедака „како би оне могле послужити његовој замисли о чистоти народног језика, и уздизању националног духа", Нада Милошевић Ђорђевић закључује да је Вук истовремено стасавао и „као редактор, стилизатор, приповедач и уметник”: „Он је створио један облик приповетке који је био од далекосежног утицаја на касније сакупљаче и створио код нас уопште, један појам народне приповетке као искључиво сеоско-пасторалне форме, помало апстрактне и врло блиске идеји о идеалном облику бајке - какав је (преко Гримових збирки) сагледао и блиставо анализирао Макс Лити (Max Lüthi) (Das Europäische Volksmärchen, Bern 1947, München 1962) (252). У одломку прилога Немање Радуловића „Вук и Механџић: проблем схватања народне приповетке" као да се допуњава горе изложено сматрање о канонизацији Вукових збирки народних умотворина:

„Када је о приповеткама реч, није претеривање ако кажемо да је слика народних приповедака не само канонизовани Вук него и оно што је дао Механџић. Примећено је да је слика Марка Краљевића коју савремени читалац има, заправо, Марко како га представља Тешан Подруговић. По аналогији може се рећи да је слика српске народне приповетке, нарочито бајке, данас оно што је дао Механџић, а прерадио Вук. Лако се намећу паралеле са браћом Грим и канонизацијом Дечијих и домаћих бајки у немачкој култури" (Исто: 257-258).

У едицији „Портрет књижевног дела” Завода за уџбенике и наставна средства, Миодраг Поповић је 1983. године објавио можда своју најзначајнију научну књигу: Памтивек. Српски рјечник Вука Ст. Карацића. У овој својеврсној монографији о можда превратнички најзначајнијој књизи српске књижевности, посебно су занимљива поглавља посвећена појединим слојевима Рјечника као својеврсног памтивека српске духовности: Митски лексички извори (обухваћено је обиље митских појмова); Пагански слојеви (у здравицама, култним легендама, пословицама и празничним обредима посебно, Поповић прати успомену на старе богове, као и трагове матријархата); Хришћанство; Оријент (посебно су занимљива проматрања Насредин-хоџиних досетки као моста између Истока и српске сеоске заједнице, као и Вуков однос према турцизмима и оријентализмима, при чему нам пружа обилну лексичку грађу на седамнаест штампаних страница, Поповић 1983: 30-47). Изузетно су занимљива Поповићева опажања разлика у језику првог и другог издања $C p$ пског рјечника која се тичу ширења вокабулара и обухватања све ширег круга које покривају појмови: „Срби сви и свуда” и „Срби сва три закона”, при чему укључује битне елементе и источнога и западнога говорног подручја, а искључује дијалектолошке екстреме (чакавски, кајкавски, торлачки), ,те тако крчи путеве стварању наддијалектолошког српскохрватског књижевног језика". Чврстом вером у будућност наддијалекатског српскохтватског језика Вук се очигледно определио „не само за народни већ и за општенародни језик" (Исто: 143).

Када је реч о причама о речима, оне Поповићу служе да покаже како траје процес Вуковог „покњижевљавања народног говора” (Исто: 144-160). По њему, на 
Вука су утицала сва три постојећа књижевна језика у Срба када је почео да ради на Рјечнику: славеносербски, народни књижевни језик и тада већ мртав српскословен$c \kappa u$ : „Чистећи српски језик од русизама и хибридне славеносербске морфологије, Вук у извесној мери преузима оно што се складно уклапа у народни књижевни језик и из славеносербске лексике. Нешто слично чини и са српскословенским речима у преводу Новог завјета”. Поповић сматра да „оптужбе против Вука због тобожњег духовног и интелектуалног осиромашења књижевног језика, које се чују све до данас, више се заснивају на Вуковим изјавама из раног периода његова рада него ли на самом Вуковом језику” (Исто: 145). И начин писања кратких прича о речима, у којима се Вук држао у већој мери народног говора као основе будућег српског књижевног језика, допринео је да Поповић дође до закључка да је такав језик сматран „од стране његових ускогрудих следбеника као Вуков лични језика и стил за књижевну норму (не само граматичку). Тиме су они увелико утрли пут фолклоризацији српске књижевности” (Исто: 146).

Да би показао колико је сложен одговор на питање којим језиком Вук говори и пише почетком 19. века, Поповић посебно издваја Вуков језик полемика, језик превода Новог завјета, језик Српског рјечника. Када говори о трећем, „главном члану Вуковог језичког тројства", блиском народном говорном језику, Поповић истиче да се он први пут јавља у написима и огледима уз поједине речи у Рјечнику 1818. године: „Њиме или, прецизније, једном његовом варијантом Вук ће писати и устаничку прозу и приповетке. И у њему, у граматичко-морфолошком смислу, Вук је дао образац истог језика; само нешто другачији: разлике су лексичке, звуковне и само делом синтаксичке" (Исто: 148). Миодраг Поповић језик Вуковог Рјечника сматра синтезом живога говора и постојећег песничког (усменог) језика, при чему се они развијају, „претачу у модерно књижевно писмо”: „Вуков језик у Рјечнику није фолклорни, већ народни књижевни саздан на претежно говорној основи. Вуков писани текст често делује на читаоца као живи народни говор. Илузију усмености, поред управног говора и мемоарског казивања, стварају и обрти из свакодневног живота које писац често уткива у свој текст [...] Илузију усмености некад појачавају и пословице које се, као и у говору спонтано јављају у Вуковом тексту" (Исто: 152-153). У разликама прича о речима између издања Рјечника из 1818. и 1852. године, Поповић показује како је Вуков језик постајао све пунији, богатији, разуђенији, па и књижевнији, а текст литерарнији - ,живи говор се претварао у добар књижевни језик, у коме је свака реч нашла своје место” (Исто: 155). „Вуково намештање речи имало је несумњиво велику улогу у покњижевљавању народног говора [...] Вуку је поред тачног тумачења речи било стало и до њене лепоте, свежине, непохабаности". Тако је, закључује Поповић, Рјечник од лексикографског подвига прерастао у књижевно дело изузетне вредности, несумњиво једно од највећих у свом времену” (Исто: 157-159).

Двострука улога Вуковог Рјечника, да истовремено буде и читанка о народу и књига за народ, допринела је да преузме и улогу алманаха, магазина, забавника, форме класичног књижевног периодика с краја 18. и првих деценија 19. века, чији централни садржај чини „ковчежић” крцат народним умотворинама, Вуковим мемоарским и путописним упамћењима и преношењем читаоцима онога што је народ сматрао „паметодостојним”. Поповић детаљно представља готово све усмене обли- 
ке који се у њему находе са лексикографском наменом, али у избору који представља и естетске њихове вредности, Вук их „Књижевно оплемењује”: изреке (благослови, поздрави, заклетве), басме, клетве као антибасме, читав систем поништавања окретањем ствари и ритуалних радњи „наопако”, све до погребног „кола наопаког” које помаже мртвом да лакше оде на онај свет, и ношења копља „наопако” за мртвим јунаком, што потиче још од доба варварства, загонетке, пословице, изреке, „у обичај узете речи" (и у Рјечнику Вук не истиче јасну границу између изрека и пословица, иако наводи пет стотина примера ових усмених облика), ругалице, тужбалице, молитве, беседе (здравице), обредне песме, лирске минијатуре, преткућнице, попијевке, подскочице, шаљиве и дечје песме, епске фрагменте у десетерцима, анегдоте, шаљиве приповетке, легенде, херојске скаске, приче о животињама, демонолошка предања, каже, гатке, гаталице, ритуалне записе, описе друштвених и витешких игара. У овим усменим књижевним формама Вук нам открива етнички и естетички идентитет српског народа, оне одговарају тренутку у коме настају и стилизоване су тако да се налазе на средини фолклорних жанрова и књижевних врста. У том процесу све је у настајању, у живом преплитању говореног и литерарног: „У Pjeчнику иначе доминира слободна нарација, казивање. Вук не подучава, не загонета, не беседи; он прича, управо ствара. Њега мање привлаче опште (пословичне) истине и реторички искази. Занимају га и конкретни детаљи, али га посебно привлачи оно што људи приповиједају и о чему маштају" (Исто: 169).

Где треба у Вуковом Рјечнику тражити приче о речима? Свакако међу четрдесетак омањих приповедака и хумористичких анегдота, међу многим легендама, у мањем броју скаски и малобројним причама о животињама, у демонолошким предањима, комадима бајки, деловима митова о Милошу Обилићу, Сибињанин Јанку, Марку Краљевићу, Змају Огњеном Вуку... Поповић овоме придодаје и Вукове прозне записе као својеврсни мозаички речник-летопис народа (средњовековног порекла, инспирисаних Библијом или устаничким временима), омање огледе (развијене записе, посебно у издању Рјечника из 1852), као и ритуалне сценарије (драматизације са дијалозима). Он с правом Вукове „ђекоје мале приповијетке” у Рјечнику из 1818. године проглашава „првим српским прозним делима објављеним на чистом народном језику". Те приповетке, примећује, Вук наводи као народно казивање („Приповиједају”; „Приповиједали су ми”), али он у њима гради сажету композицију, без дигресија и излишних метафора, зачињује их сатирично-ироничним хумором уз помоћ „агресивно-агоналног менталитета патријархалног света” или префињеном иронијом када се приповеда о свету који је досегао „културно оплемењени менталитет”. Те „ђекоје мале приповијетке” исприповедане су тако као да их усмени приповедач ствара тог тренутка а не као брижљиво клесану књижевну прозу” (Исто: 170-171).

Поповић уочава и живо преплитање и мешање појединих облика, да су мотиви из бајке расути по демонолошким предањима, по скаскама и легендама, по митолошким записима, да су засути стиховима лирским и епским; много шта се илуструје и притврђује, налазимо облике фантастике које тек треба да прерасте у бајку, пуно је легенди и скаски у настајању. То посебно важи за скаске, које у речнику најчешће остају кратке и неразвијене, поготову оне демонолошке, о вештицама, вукодлацима, ђаволима, грабанцијашима, вилама, аждаји и о свакојаким другим 
бићима и „стварима којијех нема”. Посебно су занимљиве легенде праћене причама о постању појединих места, именовању локалитета, природних феномена, те о појединим митолошким или историјским личностима, за које се везују и предања за одређене локалитете: Проклета Јерина (Голубац, Козјак), Старина Новак (Бишина), војвода Момчило (Пирлитор), Смиљанић Илија (Вучјак), Милош Обилић (Двориште), Марко Краљевић (Прилеп и још десетак локалитета које народ везује за Марка). Поповић истиче да легенде о неким јунацима (о Милошу Обилићу, Змај Огњеном Вуку, Сибињанин Јанку) често у себе укључују и митолошка предања, да се легенда о њима често преображава у јуначку скаску (Исто: 173), као што неке легенде и скаске прелазе у херојска житија. Управо Миодраг Поповић прејудицира каснију претпоставку Мира Вуксановића да Српски рјечник садржи у себи праискру постмодернистичке форме речника-романа, коју ће маестрално остварити Милорад Павић у свом у свету прихваћеном делу Хазарски речник (1984): „Напис о Краљевићу Марку такође је сплет херојских легенди и скаски, које се међусобно прожимају и асоцијативним путем уланчавају у целину. Тако начињена „приповедачка” целина такође делује као мозаичко херојско житије" (Исто: 174).

У оквиру едиције Матице српске „Десет векова српске књижевности”, Миро Вуксановић је приредио књигу Вука Стеф. Караџића под насловом Српски рјечник или азбучни роман (2012), у којој је сабрао књижевне делове првог и другог издања Рјечника. Његов избор подразумевао је речи ,испод којих су кратки прозни облици усмене књижевности (пословице, загонетке, питалице, разговорчићи, изреке, устаљене фразе и друго), са свим таквим објашњењима” (Исто: 523). У уводној студији под насловом „Књига над књигама”, Вуксановић издваја Вуков Рјечник као „темељник новије српске књижевности” и „етнографски лексикон”, као књигу у којој се, када је реч о приповедању и приповедним деловима, „Вук Караџић јавља као писац, а сви ти делови као књижевност” (Исто: 25), да је то ,једина књига из његовог доба која је и данас отворена" (Исто: 37). Оно што Вуксановић чини када је реч о „отварању” Вуковог Рјечника у нашем времену јесте управо промишљање ове књиге, сврставање обрада појединих речи по облицима, по жанровима, при чему се структура Рјечника разбија на више азбучних целина. Пред нама се, тако, указује нарочит ,азбучни енциклопедијски роман, роман лексикон у исто време”, у коме „лежи попут некаквог, дубоко закопаног блага, читав један свет наше литературе” (26). Вуксановић је свестан да Вук „није могао наслућивати романескну структуру у свом Рјечнику, али је повезао чињеницу да је уредник књиге Расковник Радомира Константиновића био Милорад Павић, аутор Хазарског речника (1984). Он нам скреће пажњу и на још нека слична дела којима је Вуков Рјечник „био први и далеки предак”, пре свега на дела Ђорђа Марковића Кодера (Начала и Наречено, која су приредили и објавили Весна Малбашки -Пуповац и Сава Дамјанов 2008. и 2011. године), како би претпоставио да је Вук: „Српским рјечником (као књижевним делом!) антиципирао неке аспекте будућег српског лексиконског и енциклопедијског романа, најпотпуније оствареног баш у Хазарском речнику” (Исто: 26-27).

На правцу читања Вуковог Рјечника као уметничког дела - романа-речника - Вуксановић упућује на књигу Јована Делића Традиција и Вук Стеф. Карацић (1990). Делић на издвојеним наративним тематским целинама показује начин могућег уланчавања сложенијих прича о речима (Милош Војиновић, Мрюавчевићи и 
Марица, Видовдан, Косово, Честити Кнез, Милош Обилић, Бановић Страхиња, Високи Стефан, Косовски мит у Првом устанку), да би за „роман-мозаик” о Марку Краљевићу из Вуковог Рјечника закључио да у њему налазимо „један од најмодернијих, најбољих и најсложенијих ликова што их је дала наша књижевност" (Исто: 27-28).

Одрживост те линије речничког романсирања, снажног трага прича о речима у српској књижевности (кључне координате: Вук, Кодер, Павић) можемо притврдити и неким паралелама које се находе у књижевној периодици с краја 19. и у 20. веку, посебно код песника језикотвораца попут Лазе Костића и Васка Попе, али и у богатој есејистици и прози аутора код којих је у великој мери постојала присутна свест о чаробности и значају малих прича о речима за снажење и творење књижевног језика, без обзира да ли је то у склопу лексикографске грађе или прозних и есејистичких огледа о језику.

Могућност умрежавања мозаика о једној историјској личности по угледу на Вуково искуство у Рјечнику, Павић вешто остварује на примеру више одељака $X a$ зарског речника посвећених Столпнику Гргуру Бранковићу (1676-1701), при чему користи чак и упутнице, он попут Вука у речник уноси пословице са пропратним тумачењима („Најтеже је орати туђу њиву и своју жену - бележи он - али пошто је сваки човек разапет на својој жени као на крсту, излази да је теже носити свој него туђи крст”, Поповић 1984: 57), користи многе вуковске наративне форме за тумачење речи: записе, повести итд. Да ова линија дуго протрајава у српској књижевности, најбоље сведочи Павићева обрада лика Скиле Аверкија (XVII -почетак XVIII века), који је објавио искуство мачеваоца и сабљаша 1702. године у књизи Најлепши потписи сабљом. И луталица Ђорђе Марковић Кодер скрасио се једно време у Београду и Темишвару, где је отварао школе мачевања. Док је једном приликом боравио у Цариграду, стигао је глас о Шлимановом открићу Троје. Он зграби пртљаг под мишку, штап у руку, мач о пасу, па одмах пешице крене да посети те чувене развалине. Реч је о песнику који је страсно годинама преводио Илијаду (више хиљада стихова тог превода пропало је у рукопису), за кога је изгубљена Троја била животна фикција. У својим белешкама он оставља податак да је лутао данима по развалинама Троје, поносан што може да каже: „Да, ја сам био први Србин који је угледао зидине Троје!” И тада је, врхом мача, на једном тек ископаном зиду, црквеним словима исписао своје име". Био је то, да подсетим на Скилу Аверкија, најлепши српски потпис сабљом за сва времена. А Кодерови записи о значењима речи теза, пчеле, којих нема у првом издању Вуковог Рјечника, начињени су као да je Кодерову руку водила Вукова лексикографска и књижевничка рука. У њима сам и ја пронашао грађу за две Кодерове приче о речима и уклопио их у приповетку „Упокојење Ђорђа Марковића Кодера" објављену у збирци Сеновите приче (2008):

„Све је у једном гласу, у гласу з. Тај глас ми је открио суштину човечијег бића и језика. Питао сам се коју је природну храну човек прву открио, а да није из земље, богомдани плод, већ нешто што се ствара. Нећете веровати, био је то мед. Зато медом мажу довратак, и бадњак. Гледао сам то толико пута, и код других народа шта са медом чине. И при том нешто роморе што по гласу наликује зују. Глас з, да, пчелињи глас је било прво људско оглашавање. Хватали су се, као пчеле, у коло лицем окренути један другом, и испуштали су глас з: 3, 3, 3, 3, з... Док је било тог гласа, нико се из тог кола није пуштао. Тако је почео људски род, тако се зачео говор. И прве настамбе настајале су попут пчелињег роја, све су се на пчеле угледали, као да им оне долазе са онога света да их подуче 
и окрену људскости. Захваљујући пчелама, настале су и прве заједнице, и међу њима издвајала се мајка матица коју су следили и за коју су били спремни и мед да донесу и да убоду иако им иза убода није преостало живота.

Онда сам бирао речи у којима је важно место заузимао глас з. Теза, на пример. И схватим колико је велик рој појмова око те речи, колика је густина језика ако се тако гледа на његово постање. Теза је име материно. Дете чека тезу да га нахране. Док тражи жртву и шестари, орао је у тези. Теза је птиче полетарче што не сме да излети из гнезда, птица несмелица. У разбоју теза је основа. Теза је знак оком да се сачека, да се нешто не твори. Теза је свећа која оклева да се разгори. Теза је во који неједнако вуче, особа која оклева да воду прегази, паук се тезом доле срозава. Башта је у тези кад воће позни, воће је у тези ако лагано у трулеж прелази. Дрво у тези црв тешко точи, лист је у тези ако заостане на грани и ако му је одавно било време да отпадне. Неки су тезе у јелу, или опелу. Теза је 'налик-зора' која се јавља око Божића, после које, најпре, мрак дође, па тек онда сване дан. Невеста је теза док отеже да са сватовима напусти родитељску кућу. Млеко које крава за теле 'затаји' теза је, и оно је најбоље. Сабља кад се из корица тешко извлачи теза је. И онај простор плави од једног сјајног небеског тела до другог теза је небеска, и птица кад издише и истеже ноге и крила у смртној је тези, и сунце зубато је теза, и мушмула која никако да угњили, и руже и пупољци који позне, па и она црна смоква арнаутка, па самртник који тешко умире. И Мом који оклева да ме прими, па сам ја у тези” (Исто: 192-193).

Управо на примеру речи теза коју Вук није унео у Српски рјечник Кодер је показао како се ослобађа енергија живог језика, да је Вук идући усмерењем на народни језик, можда и ненамерно, запоставио вокабулар „предвуковског језика”, који би тек требало да се начини по могућству на Кодеров начин.

Најзад, паралела делова људског тела са словима из антологијске песме Лазе Костића „Спомен на Руварца”, као завршни акорд ове величанствене Костићеве песме, они његови стихови о алфи и омеги - глави и телу човечјем оживели су у Павићевом Хазарском речнику:

„Како слова земаљске азбуке одговарају свако по једном делу човечијег тела, тако слова небеске азбуке одговарају свако делу тела Адама Кадмона, док белине између слова означавају ритам покрета тела. Али, пошто напоредност божије и људске азбуке није допустива, увек се једна од њих повлачи да би начинила места другој и обратно, кад се друга шири, прва је у узмаку. То вреди и за писмена Библије - Библија стално дише" (Исто: 168).

Да додам, тако је и са Вуковим Рјечником памтивека српског. Крај песме Лазе Костића гласи:

„Алфа и омега!

О мудра смрти, о самртничка, жива мудрости!

Алфа је глава, алфа, то је ум, почетак свега, душин неимар, што у њој зида будућности сјај; а омега, јест, омега је кук, срамота, трбух, лакомост и блуд, зидара умног вечни рушитруд то омега је свему, свему крај." 


\section{Литература}

Вуксановић М. Српски рјечник или азбучни роман. Књижевни делови првог и другог издања $(1818,1852)$. Десет векова српске књижевности, књ. 107. Нови Сад: Издавачки центар Матице српске, 2012.

Делић Ј. Традииија и Вук Стеф. Караиић. Београд, 1990.

Караџић В. С. „Углед народног језика у прози.” Самарџија С. Народне приповетке и предања. 2017: стр. 247-248.

Константиновић Р. Расковник. Проза из Рјечника. Београд: Издавачко предузеће Просвета, 1964.

Марковић Кодер Ђ. Начала. Приредили Весна Малбашки Пуповац, Сава Дамјанов. Београд, 2008.

Марковић Кодер Ђ. Нареченно. Приредили Сава Дамјанов, Весна Малбашки Пуповац. Београд, 2011.

Матицки М. Сеновите приче. Београд: Атлас - СКЗ, 2008.

Матицки М. Вук Караиић, Српске народне приповијетке. Предговор и приређивање Миодраг Матицки. Београд: Вукова задужбина - Лагуна, 2017.

Милошевић Ђорђевић Н. „Преглед прозних облика наше усмене књижевности.” Самарџија С. Народне приповетке и предања. 2017: стр. 249-256.

Павић М. Хазарски речник. Роман лексикон у 100-000 речи. Београд: Просвета, 1984.

Петровић Б., Трећаков С. Вук Стеф. Караиић, Мале приче. Изабрали и приредили Бошко Петровић и Стојан Трећаков. Нови Сад: Матица српска, 2000.

Радуловић Н. „Вук Механџић: Проблем схватања народне приповетке.” Самарџија С. Народне приповетке и предања. 2017: стр. 257-265.

Самарџија С. Народне приповетке и предања. Приредила Снежана Самарџија. Десет векова српске књижевности, књ. 10. Нови Сад: Издавачки центар Матице српске, 2017.

Сувајџић Б. „Андрић о Вуку.” Даница, српски народни илустровани календар за годину 2018, год. 25 (2017): стр. 111-124.

Popa V. Od zlata jabuka. Rukovet narodnih umotvorina. Beograd: Nolit, 1979a. [1958]

Popa V. Urnebesnik. Zbornik pesničkog humora. Beograd: Nolit, 1979б. [1960]

Popa V. Ponoćno sunce. Zbornik pesničkih snoviđenja. Beograd: Nolit, 1979в. [1962]

Popović M. Pamtivek. Srpski rječnik Vuka St. Karadžića. Beograd: Bibliotreka „Portret književnog dela" - Zavod za udžbenike i nastavna sredstva, 1983. 


\author{
Миодраг С. Матицки
}

\title{
РАССКАЗЫ О СЛОВАХ
}

\section{Резюме}

Издательство «Вукова задужбина», совместно с издательским домом «Лагуна», опубликовало в 2017 году том «Сербские народные сказки» (Српске народне приповијетке), в котором помимо одноименного сборника Вука [Караджича], опубликованного в Вене в 1853 году, собраны и другие сказки Вука из отдельных изданий: переиздания сборника стихов из приложения к Новине сербске (1821), сказки из рукописи, опубликованной в 1870 году вдовой Вука Аной, подготовленной его дочерью Миной, а также те сказки, о которых Вук говорит, что они народные, из его венского журнала Даница.

К печати подготовлен второй том историй Вука под названием «Рассказы о словах» (Приче о речима). В него вошли краткие повествовательные формы, которыми Вук объяснял слова в «Сербском словаре $(1818 ; 1852)$ и «Народных сербских пословицах и поговорках» (Народне српске пословице и друге различне као оне у обичај узете ријечи) (1836), так как за каждой пословицей стоит рассказ, повествовательная ситуация, из которой произошла пословица. В этом томе реконструирован сложный путь становления Вука как сказителя и собирателя сербских народных сказок, эта книга обязательно станет большим подспорьем для исследователей сербской художественной прозы, с момента появления «Сербского словаря».

В «Сербском словаре» 1818 года мы обнаруживаем обилие повествовательных заметок, показывающих, что Вук в то время усиленно учился, как устное сказание превратить в письменную форму, краткую и эффектную в той мере, чтобы ее приняли слушатели. Здесь он нарабатывал мастерство обработки сербской устной прозы, развивал врожденный талант доработки устного сказания, иногда только синопсис народной сказки, которую он слышал, но не мог напрямую записать, как он это делал с песнями, куплет за куплетом. Он научился дорабатывать свою устную прозу в соответствии с манерой устного повествования, подразумевающей прямое обращение и сценическое представление, со всеми движениями и говорящими паузами, позволяющими удерживать внимание слушателей.

В сербской литературной периодике XVIII и XIX века, впрочем, на протяжении десятилетий преимущественно преобладали короткие рассказы с моралью, которые «держали» внимание читателей, которые базировались на анекдоте или были умело вырваны из эпического повествования, которое в самой своей основе содержит устное сказание. Сокращения в основном реализовывались при помощи вставки пословиц и поговорок, фраз, которые были общеузнаваемы. В этом состоит суть исключительности народной сказки Вука, одна из основ «нового направления в сербской литературе», которым мы обязаны Вуку не только из-за реформы языка и письма, но и из-за если и не радикального поворота в сербской прозе XIX века, но, в любом случае, изменения направления художественного повествования.

Этот подход утверждается в сербской литературной периодике времен Вука, прежде всего, редактируемой вуковцами первого ряда, хотя не следует забывать факт, что и сказки Вука во множестве переиздавались в газетах, альманахах и календарях, при этом, как это произошло и с народными песнями, не все и не подряд, так что можно составить типологию переиздания сербской устной прозы в периодике, восполнявшей недостаток аутентичной сербской прозаической продукции. Таким образом создавалась единое, всеобщее сербское устное наследие, выделялось все самое ценное, имевшееся в местной традиции.

Народная сказка начала при помощи литературной периодики все сильнее влиять на писателейпрозаиков путем внесения кратких прозаических устных форм, заимствования образов, ситуаций, острот устного происхождения. Целые сборники народных сказок Вука заискрятся в сербской прозе, да и в комедии. Только на основании мотивов соперничества во лжи («Ложь на спор», «Один врет, другой помогает»), соперничества в хитрости святых и дьявола написаны многие успешные юмористические рассказы и комедии.

Великие мастера сербской поэзии и прозы предугадали, какие залежи мифических пластов, превращения легенды в миф, поэтической чувствительности, повествовательной фикции и сновидения, высвобождения юмора при помощи владения им как средством освобождения личности от рутины и бед, кроется в народных сказках, особенно тех, коротких, и прежде всего, в рассказах о словах. К сказкам Вука не без оснований обращались крупнейшие сербские писатели второй половины XX века, даже приверженцы самых современных направлений в сербской литературе. Невозможно обойти внимани- 
ем заметки Иво Андрича о Вуке (девять исследований, эссе, юбилейных обзоров и статей), антологии устного/народного творчества Васко Попа (Од злата јабука, 1958); Урнебесник, 1960; Поноћно сунце, 1962), великого романиста Бошко Петровича, автора романа о Тешане Подруговиче - «Певец» (Певач), который вместе со Стояном Тречаковым собрал и подготовил в издании «Матицы сербской» малую антологию «рассказов о словах» Вука (Мале приче, 1987; второе дополненное издание - 2000). Когда речь идет о пословицах и поговорках как своего рода рассказах о словах, особое значение имеет книга Радомира Константиновича, который в издании «Просвета» в 1964 году, к столетнему юбилею смерти Вука, опубликовал книгу Расковник. Проза из Рјечника, сопроводив свой выбор весьма внушительным исследованием. В сотрудничестве с Васко Попа Миодраг Попович в 1983 году опубликовал книгу о «Сербском словаре» Вука Стеф. Караджича - Памтивек, единый портрет этой книги Вука, которая покоперниковски перевернула течения сербской литературы и сербского литературного языка. По большей части он касается кратких прозаических форм, которыми Вук объяснял фразеологизмы, будь они спрессованы в пословицы, поговорки, веру в «то, что не может быть», или изустной памяти о мифических и исторических личностях, отмеченных в истории сербского народа. Миро Вуксанович, редактор издания «Матицы сербской» «Десять веков сербской литературы», как писатель-прозаик, лучшие страницы своих прозаических произведений посвятивший словам, подготовил в 2012 году для этого издания «Сербский словарь» Вука. Во вступлении он открыл нам постмодернистские предложения Вука, касающиеся жанра словаря-романа, какой в XX веке выпустил в свет Милорад Павич со своим «Хазарским словарем» (1984) и какой, добавим, предвидел еще Джордже Маркович Кодер в своих рассказах о журчании, как праначале языка.

Ключевые слова: «Словарь» Вука, рассказы о словах, пословицы, поговорки, анекдоты, юмористические рассказы, сказки, роман-словарь, сербская проза. 